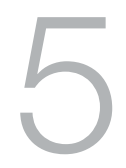

\title{
Reconsidering What Constitutes Objective Decision-making About Children Crossing International Borders
}

\author{
Joanne Kinslor ${ }^{1}$
}

This chapter discusses unintended consequences that arise from the application of Australia's child custody visa requirement referred to as Public Interest Criterion 4015 (PIC 4015). It questions whether the requirement serves the role for which it was designed, both in terms of the nature and the outcomes of decision-making it supports.

PIC 4015 requires that unless all parents/guardians can and do consent to a child's travel to Australia, in most cases a child's ability to travel to Australia will be determined by reference to the law of their home country.

As the policy of the Department of Immigration and Border Protection (DIBP) explains, the primary purpose of this child custody requirement is to ensure that Australia does not facilitate international child abduction. PIC 4015 seeks to give effect to Australia's international obligations, especially those under the Hague Convention on the Civil Aspects of International Child Abduction (the Hague Convention).

1 The author is grateful to Emeritus Professor Reg Graycar for her comments. 
The High Court case of Tahiri $v$ Minister for Immigration and Citizenship (Tahiri) highlights how a provision designed to protect the welfare of children through preventing child abduction can have the effect of preventing children coming to Australia where no issue of child abduction arises and where the Hague Convention does not apply.

While PIC 4015 was said to introduce an objective test for determining child custody, Tahiri demonstrates how the provision's focus upon the family law of foreign countries instead facilitates discrimination against women.

\section{Introduction}

The case of Tahiri raises the question of how a law (PIC 4015) designed for the protection of children led to a family of refugees (comprising a sole parent - an Afghan Hazara woman - and her children) being refused humanitarian visas. How could the only reason for refusal of their visas and migration to the safety of Australia be that they failed to meet a visa requirement designed to uphold international law for the protection of children?

Learning that this result arose because Australian law gave effect to Afghan family law raises the further query of why Australia, a country committed to sex equality, ${ }^{2}$ would maintain a law giving effect to a strongly patriarchal system of law. This law, characterised as an objective test for deciding child custody issues between parents/ guardians, instead prioritised the custody rights of a missing and absent father while denying the rights and responsibility of a mother engaged in full-time care for those children.

This chapter considers whether such results constitute the unintended, but necessary, consequences of Australia upholding the Hague Convention. It concludes that the law is inconsistent with the terms of the Hague Convention and is not justified on the basis that Australia needs to uphold its obligations under the convention. Rather, for the reasons outlined below, it suggests that Australia should be concerned

2 Notably, in the migration context, all applicants for Australian visas are required to acknowledge an Australian values statement, which includes the following: Australian society values respect for ... equality of men and women'. Migration Regulations 1994 (Cth) sch 4 item 4019. 
that the law impedes our nation in upholding international law, such as our obligations under the Convention on the Rights of the Child, which requires that the best interests of children be a primary consideration in administrative decision-making, and the Convention on the Elimination of All Forms of Discrimination against Women.

The chapter begins by discussing the facts of the High Court case of Tahiri and the terms of the law that applied in that case, PIC 4015. The discussion focuses upon the unintended and interrelated impacts of applying PIC 4015, which excludes consideration of the best interests of children to whom it applies and discriminates against women. The chapter explains how PIC 4015 was designed with Australia's obligations under the Hague Convention as a main concern, but that the limited considerations permitted by its terms do not allow assessment of when the Hague Convention applies or the exceptional circumstances covered by the convention. The chapter concludes that decision-makers require further scope to consider relevant factors if they are to be equipped to make decisions upholding policy objectives and Australian international legal obligations amongst the varied and complex cases that inevitably arise about children crossing international borders.

\section{The Case: Tahiri v Minister for Immigration and Citizenship [2012] HCA 61 13 December 2012, 293 ALR 526}

Tahiri concerned an offshore humanitarian visa application by an Afghan Hazara woman, Mrs Tahiri. ${ }^{3}$ In early 2003, Mrs Tahiri's husband left the family in Jaghori, Ghazni province, Afghanistan, to travel to the province of Kandahar. Mrs Tahiri was pregnant with their sixth child at the time her husband left, and this child was born later in the same year.

3 The summary of facts is taken from the written submissions the plaintiff and the defendant submitted to the High Court in Tahiriv Minister for Immigration and Citizenship Case No. M77/2012. Available at: www.hcourt.gov.au/cases/cases_m77-2012. Facts are also from the judgement of the High Court Tahiri v Minister for Immigration and Citizenship (2012) 293 ALR 526. 
Mrs Tahiri had no contact from her husband after his departure and no communication from any source about his whereabouts or welfare. After losing contact with her husband she travelled to Pakistan with all her children in 2003. They lived together as refugees in Quetta, Pakistan, without any right of residence, until at least 2012. Quetta is a city where many thousands of Afghan Hazaras have fled to escape persecution, particularly on account of atrocities committed by the Taliban against Hazaras. ${ }^{4}$

In 2009, Mrs Tahiri's eldest son, Javed Hussain (the plaintiff in the High Court case), travelled to Australia as an unaccompanied minor. He was recognised as a refugee and granted a protection visa permitting him to live in Australia permanently. He proposed his mother for an offshore humanitarian visa, ${ }^{5}$ which included his siblings. Mrs Tahiri's visa application was refused on 2 January 2012 because she could not satisfy the delegate considering the application that she had custody of her four youngest children ${ }^{6}$ in the terms required by the migration regulations. Specifically, Mrs Tahiri was refused her visa because her children under 18 years of age did not meet PIC 4015, which is discussed in detail below. ${ }^{7}$ This requirement is distinct from the requirements specific to the visa being applied for - in Mrs Tahiri's case, a humanitarian visa that required that she was the parent of a person who held a protection visa (her son, Javed).

Mrs Tahiri's uncontradicted evidence was that she had moved her children from Afghanistan to Pakistan and had cared for them as a sole parent for almost nine years, since her husband went missing. The delegate accepted that her husband had been missing since 2003 and had no involvement with the children since then. Before the High Court it was pointed out that, given Quetta is a place where many Afghan Hazaras have fled to escape the Taliban, it would have been an obvious location for her husband to search for his family if he were

4 See, for example, UK Home Office, 'Pakistan Country of Origin Information (COI) Report' (9 August 2013) 172-174.

5 Subclass 202 Refugee and Humanitarian (Class XB) visa.

6 Her eldest daughter was married and not included in the visa application when it was decided.

$7 \quad$ Specifically Migration Regulations 1994 (Cth) sch 2 cl 202.228. This criterion required Mrs Tahiri to establish that each member of her family unit who had not turned 18 and had made a combined visa application with her satisfied PIC 4015 (and 4016) before she was eligible for her visa. In addition, each of the children had to meet equivalent criteria (PIC 4017 and 4018) to be eligible for their visas. 
alive. Since he had been missing for more than seven years, it was argued that the common law presumption of death applied - that is, a person will be presumed dead if they have been missing for a period of at least seven years. ${ }^{8}$

The delegate refused the visa without deciding whether Mrs Tahiri's husband was alive or dead. He first found that the applicable law governing custody of the children was the law of Afghanistan (not Pakistan). He found that if her husband were alive, under Afghan law he had the right to determine where the children were to live and if he were dead that right passed to his family. The delegate (who was not required to provide reasons for his decision) ${ }^{9}$ is recorded as concluding:

In both Afghan law and custom, the custody of the minor children would fall to the father's side if there were credible and substantial evidence of the death of the father.$^{10}$

Nothing more specific than that conclusion was given. No source references were provided for the delegate's understanding of Afghan law and custom. His conclusion as to how Afghan law and custom operated was not challenged ${ }^{11}$ by the plaintiff nor referenced by the defendant. In oral submissions, the solicitor general noted that the delegate was based in Dubai and 'probably had many applications of this kind' and 'had built up a knowledge base or view of Afghan law'. ${ }^{12}$

Nor was the finding any more specific than custody going to the 'father's side' if Mrs Tahiri's husband were dead. No specific member of the family or type of relationship was identified. Given the

\footnotetext{
8 Javed Hussain Tahiri, 'Plaintiff's Submission', Submission in Tahiri $v$ Minister for Immigration and Citizenship, No M77/2012, 21 November 2012, 15. The plaintiff references the common law presumption of death as Axon v Axon (1937) 59 CLR 395, 404-405 (Dixon J).

9 The delegate was only required to notify Mrs Tahiri of the criterion that was not satisfied and led to refusal of the visa. Migration Act 1958 (Cth) s66. The findings of the delegate discussed were drawn from records in the file. See Tahiriv Minister for Immigration and Citizenship (2012) 293 ALR 526, 9.

10 Javed Hussain Tahiri, 'Plaintiff's Submission', Submission in Tahiri $v$ Minister for Immigration and Citizenship, No M77/2012, 21 November 2012, 9.

11 It must be noted that the review before the High Court of Australia was limited to judicial review on the grounds of jurisdictional error - not merits review. A decision-maker can commit a jurisdictional error by making a finding of fact for which there is no evidence. The plaintiff in Tahiri did not argue that the decision-maker had no evidence for this finding.

12 Tahiri $v$ Minister for Immigration and Citizenship [2012] HCATrans 336 (7 December 2012) 44 .
} 
patriarchal flavour of the law identified by the delegate as applying, it was implicitly assumed that the 'father's side' meant male members of the father's family, and it was noted in oral submissions before the High Court that the father had brothers who were alive, ${ }^{13}$ but nothing was established in terms of contact between Mrs Tahiri's children and their paternal uncles, any involvement by the uncles in the children's lives, or any interest by the uncles in the children's whereabouts or welfare. ${ }^{14}$

The High Court decided unanimously ${ }^{15}$ that the finding was sufficient for the visa to be refused on account of a failure to meet child custody requirements. ${ }^{16}$ The fact that the mother had had sole parental responsibility for the four children for nearly nine years ... because the father had gone missing in Afghanistan in 2003', was not disputed. ${ }^{17}$ However, it was not sufficient to establish that the delegate's conclusion was erroneous. The High Court upheld the delegate's decision as valid.

It is important to note that the High Court was not ruling upon the merits or the justice of the delegate's decision, but only upon whether the delegate had made a serious legal error (a jurisdictional error) in making his decision. Nor did the High Court rule that the delegate's conclusions were the only conclusions that could be lawfully made. The High Court found that it was open for the delegate to form the conclusions he $\mathrm{did}^{18}$ while not precluding that alternative lawful findings could have been made ${ }^{19}$ This paper does not seek to analyse the legal arguments and administrative law principles relevant to the decision. It considers Tahiri for the purpose of examining how

13 Ibid., 44, 45.

14 In oral submissions it was noted that evidence had been given that the uncles did not give them any assistance in Afghanistan. Ibid., 44.

15 The matter was heard by French CJ, Bell and Gaegler JJ who wrote a joint judgement.

16 There were two relevant requirements: PIC 4015 and PIC 4016. Both had to be met for the visa to be granted, so failure to meet PIC 4015 meant PIC 4016 did not need to be considered. These requirements are discussed below.

17 Tahiri v Minister for Immigration and Citizenship [2012] HCATrans 336 (7 December 2012) 12,13 . This was a summary of evidence accepted by the delegate and not challenged by the defendant.

18 To make his case, the plaintiff had to establish that it was not open for the delegate to come to the conclusions he did on the material that was before the delegate. This was necessary to show that the delegate had committed an error of law in circumstances in which there was no requirement for the delegate to provide reasons for his decision.

19 That would be a matter of hypothetical speculation irrelevant to the consideration of whether the decision made was valid. The significance is that other decision-makers considering similar situations may be able to make lawful decisions with differing conclusions. 
PIC 4015 operates and argues that the criterion operates in a manner that is blind to its effects in compounding discrimination against women and excluding consideration of the best interests of children. ${ }^{20}$

\section{Public Interest Criterion 4015}

Tahiri was solely focused upon the operation of PIC $4015 .^{21}$ This criterion requires that, for a visa applicant under the age of 18 , at least one of the following applies:

1. the law of the visa applicant's home country permits her/his removal;

2. each person who can lawfully determine where the applicant is to live consents to the grant of the visa; or

3. the grant of the visa would be consistent with an Australian child order. ${ }^{22}$

PIC 4015 is accompanied by PIC 4016, which requires that, for visa applicants under 18 , there is no compelling reason why grant of the visa would not be in the best interests of that child. ${ }^{23}$ The requirements are common to almost all Australian visas. ${ }^{24}$ They are not confined to humanitarian/refugee visas.

PIC 4015 is a requirement for the primary visa applicant, who will be the family head for the purpose of the visa application. If a child under 18 does not have permission to travel in the terms required by PIC 4015, it is not only the child who will be refused a visa for travel,

20 As noted below, the best interests of children is central to an additional visa requirement, PIC 4016. However, since 4015 and 4016 are separate and additional to each other, the best interests of children may be completely excluded from a decision made by reference to the interests of children, as in Tahiri. Therefore, when a matter is refused for failure to meet PIC 4015, there is no consideration of the best interests of the children as per PIC 4016.

21 Migration Regulations 1994 (Cth) sch 4, item 4015.

22 An Australian child order in PIC 4015(c) is defined as an order under s70L(1) of the Family Law Act 1975 (Cth), which covers parenting orders made by Australian courts in relation to who a child is to live with and spend time with. (See Tahiriv Minister for Immigration and Citizenship (2012) 293 ALR 526, 6.) It was not relevant in Tahiri and is unlikely to be relevant for visa applicants outside Australia, but it is an important additional option for visa applicants able to access Australian courts.

23 PIC 4015 and 4016 apply to a primary visa applicant. PIC 4017 and 4018 are in the same terms, but apply to secondary visa applicants.

24 The onshore subclass 866 protection visa is an exception. Applicants for a subclass 866 visa are not required to meet PIC 4015, 4016, 4017, or 4018. 
but also the primary applicant, who is usually a parent of the child. Therefore, in Mrs Tahiri's case, she and her children were refused humanitarian visas to come to Australia because the children did not have appropriate permission to travel.

\section{The law of the home country}

'Home country' in PIC 4015(a) is defined in the regulations ${ }^{25}$ as being a person's country of citizenship, unless the person is usually resident in another country and not usually resident in her or his country of citizenship. The default position is that the country of citizenship is the home country and can only cease to be so if the person is not usually resident there (although that is not sufficient): ' $[\mathrm{A}]$ person may not be "usually resident" in the person's country of citizenship without necessarily being "usually a resident" of another country.'26 The person's home country will only become different to their country of citizenship if she or he is usually a resident of another country.

The High Court directed that 'usually resident' in PIC 4015 should be approached as a broad factual inquiry, such as that of 'habitual residence' in the Hague Convention, taking into account 'the actual and intended length of stay in a state, the purpose of the stay, the strength of ties to the state and to any other state (both in the past and currently), [and] the degree of assimilation into the state' ${ }^{27}$

In Tahiri, the delegate found that the children's home country was their country of citizenship, Afghanistan, and the High Court upheld that approach. Although the children had lived in Pakistan since 2003 (over six years before the visa application was made), the High Court identified countervailing factors (the circumstances of their arrival in Pakistan as refugees, their being illegal residents of Pakistan, and their having visited Afghanistan) as sufficient to leave it open for the delegate to find, as a matter of fact, that Afghanistan was the children's home country, and that they were not usually residents of Pakistan. ${ }^{28}$

\footnotetext{
25 Migration Regulations 1994 (Cth) reg 1.03.

26 Tahiri $v$ Minister for Immigration and Citizenship (2012) 293 ALR 526, 15.

27 Ibid., 16.

28 Ibid., 17.
} 
As noted above, it was then sufficient for the delegate to use his general knowledge of Afghan law to decide that it did not permit the removal of Mrs Tahiri's children. Nothing was established as to any specific inquiries made by the delegate of relevant experts and the file did not record any specific reference material referred to by the delegate. ${ }^{29}$

Mrs Tahiri was given an opportunity to provide court orders from Afghanistan, but was unable to produce any - only submitting a document entitled 'Aram High Court, Kabul, Afghanistan', which she later admitted she had obtained by paying money to a person she did not know and which was not accepted as a genuine court document. ${ }^{30}$

\section{Personal consent of relevant persons}

For PIC 4015(b) to be satisfied, a delegate must first determine which persons have custody/residence rights in relation to a child and then ensure that consent is provided by each of those persons. Department policy requires written consent. This limb can never be satisfied if a relevant person is unable or unwilling to provide consent, and it is up to the parent wanting to bring the child to Australia to prove this consent.

Department policy directs that where there is no evidence of any other person having custody/residence responsibility, then delegates 'should presume that the [sponsoring] parent is the only person who needs to consent to the visa grant'. However, this is balanced by the directive that a 'non-custodial parent' who has not had contact with the child for a long time (or cannot be located) may not be assumed to consent and may have rights in relation to the child. Therefore, before a delegate can conclude that there is no evidence of someone not involved in the visa application having rights the law of the relevant country should be considered.

29 As a matter of law, it was up to Mrs Tahiri to establish that the law of the home country permitted travel and a lack of evidence would create a default position where the delegate would not be satisfied. See the Full Federal Court's discussion in Minister for Immigration \& Multicultural \& Indigenous Affairs $v$ VSAF of 2003 [2005] FCAFC 73 (10 May 2005) in relation to a requirement to be satisfied.

30 Refer to Tahiri v Minister for Immigration and Citizenship (2012) 293 ALR 526, 10. 
In Tahiri, the plaintiff argued that PIC 4015(b) should be determined according to Australian law and Australian notions of parental responsibility and guardianship, not the law of Afghanistan. ${ }^{31}$ Applying Australian law meant that the parents had the right to determine whether the children could come to Australia, but since the father could have no parental responsibility for the children (having been missing for many years), and since he should be presumed dead (having been missing for more than seven years), the only person who needed to provide consent was Mrs Tahiri.

The High Court did not accept that submission and held that the legal ability of a person to determine where a child applicant is to live 'may arise under any system of law that governs the relationship between such a person and the additional applicant' ${ }^{\prime 2}$ The court held that it was open to the delegate to decide that consent was needed either from the father or his relatives as this was required by Afghan law. ${ }^{33}$

\section{'A more objective test'? Identifying the biases embedded in the terms of PIC 4015}

PIC 4015 and 4016 were introduced by legislative amendments commencing 1 July $2000^{34}$ and replaced a requirement that the grant of a visa 'would not prejudice the rights and interests of any other person who has custody or guardianship of, or access to' a dependent child included in a visa application. ${ }^{35}$ The only explanation for the change (included in the explanatory statement) was that the new criteria provided 'a more objective test for decision-makers' ${ }^{36}$

\footnotetext{
31 Tahiri $v$ Minister for Immigration and Citizenship [2012] HCATrans 336 (7 December 2012) 7, 8.

32 Tahiri $v$ Minister for Immigration and Citizenship (2012) 293 ALR 526, 18.

33 Ibid., 21.

34 Migration Amendment Regulations 2000 (No. 2) (Cth) sch 3 pt 3.5 item 3506.

35 This requirement was included in Schedule 2 criteria for individual visas, rather than being located in Schedule 4 of the regulations. See, for example, former sub-regulation 202.228, requiring: 'If the family unit of the applicant includes a dependent child whose application was combined with the applicant's, the Minister is satisfied that the grant of the visa to the child would not prejudice the rights and interests of any other person who has custody or guardianship of, or access to, the child.'

36 Explanatory Memorandum, Migration Amendment Regulations 2000 (No. 2) (Cth). No explanation as to what purportedly made it a more objective test was provided.
} 
It is not apparent how the amended form of PIC 4015 is a more objective test. Both tests require a decision-maker to make factual determinations uninfluenced by their feelings or personal opinions. In the former test, whether prejudice or detriment would be caused to the rights and interests of a person is a question of fact specific to the circumstances of an individual case. The decision-maker needed to determine whether prejudice arises in a particular case. In the absence of an explanation, it may be that the concern was that the word 'prejudice' required potentially complex assessment of the context of a case and called for a judgement to be made by the decision-maker as to the nature of any prejudice arising in a case. Reflecting this, previous policy for decision-makers applying the previous law stated 'it is unlikely that granting a permanent visa to a child would be seen as prejudicing a person's access rights of, say, two weeks a year'.

A concern with the unexplained assertion that the test is more objective is that, used as a justification in support of the change, it implies that the current test is more neutral in how it applies to different visa applicants. Tahiri highlights how this is not the case. The test indirectly discriminates against women by giving effect to foreign laws that directly discriminate against women. ${ }^{37}$ Australia is a signatory to the Convention on the Elimination of All Forms of Discrimination against Women (CEDAW). The Australian Human Rights Commission explains: 'In signing CEDAW, Australia committed itself to being a society that promotes policies, laws, organisation, structures and attitudes that ensure women are guaranteed the same rights as men. ${ }^{38}$ Yet, our immigration law is operating to give effect to the directly discriminatory law of a country notorious for inequitable treatment of women and to the discriminatory laws of other countries. ${ }^{39}$

37 Regina Graycar and Jenny Morgan, The Hidden Gender of Law (Federation Press, 2nd edition, 2002) 28, 29.

38 Australian Human Rights Commission, The Convention on the Elimination of All Forms of Discrimination against Women (CEDAW): Sex Discrimination - International Activities. Available at: www.humanrights.gov.au/convention-elimination-all-forms-discrimination-against-womencedaw-sex-discrimination-international.

39 While I have not researched the number of countries with such laws, secondary material records that it is not only the women of Afghanistan who are directly discriminated against by their country's family law. See, for example, Akanksha Sharma and Harini Viswanathan, 'Extension of the Hague Convention to Non-Signatory Nations: A Possible Solution to Parental Child Abduction' (2011) 4 International Journal of Private Law 546. 
Regina Graycar and Jenny Morgan discuss different approaches to understanding the meaning of gender equality, including formal equality, in which everyone is treated the same regardless of their gender, and special treatment, where women are treated differently because of their difference. ${ }^{40}$ PIC 4015 is an example of the limits of formal equality. The terms of PIC 4015 do not treat women and men differently, but, as illustrated by Tahiri, PIC 4015 relies upon foreign state law that may place women and men in very different positions, and it is on account of this socially constructed difference that women and men are treated unequally. Yet, a special treatment approach creates unnecessary complexity in this case because the inequality operating is that of a foreign law. To afford women special treatment because of that foreign law is to continue to afford the law an operation within Australian law that is not required. Graycar and Morgan track the influence of Catherine MacKinnon's subordination approach to inequality, which analyses gender difference as a matter of differentiation in power between men and women. Under this model, we are able to consider the operation of PIC 4015 as compounding the powerlessness of women in context - a context that includes the position of women in Afghan law and society. This focuses attention upon the fault in PIC 4015 of giving operation to foreign law from a context with societal norms of deeply entrenched sex inequality contrary to Australian values and commitments.

While Australian immigration law impacts upon individuals outside Australia, its jurisdiction is Australia (a permission to enter and remain in Australia) and, as outlined below, Australia's international legal obligations do not require that Australia give unqualified effect to foreign legal systems.

Furthermore, indirect discrimination arises where the law of a child's home country is unable or unwilling to protect women from family violence. Women in such situations need protection for themselves and their children. PIC 4015 requires them either to obtain permission from their abusive husband/partner, or to obtain permission from the state that is failing to protect them - which may include a failure by the state to even acknowledge their right to be protected from their 
husband/partner.$^{41}$ No consideration of circumstances is permitted. PIC 4015 gives further effect to such patriarchal systems of law and government within Australian law. It fails to recognise that women in such situations are not equal before the law and by consequence will not have an equal opportunity to obtain the right to determine where their children should live.

MacKinnon writes that 'objectivity - the non-situated, universal standpoint, whether claimed or aspired to - is a denial of the existence or potency of sex inequality that tacitly participates in constructing reality from the dominant point of view' ${ }^{42}$ PIC 4015 gives effect 'objectively' - to foreign state law without any evaluation of the effect of the law. Justifying this approach as good law because it is 'more objective' denies the sex inequality of foreign state laws and, by consequence, the sex inequality of PIC 4015.

PIC 4015(a) is concerned only with the operation of foreign state law. PIC 4015(b) is concerned only with 'persons who can lawfully determine where' a child is to live. The High Court has explained this requirement as referring to a 'legal ability' to determine where a child may live that may arise 'under any system of law that governs the relationship between' the person and the child. ${ }^{43}$ Thus, PIC 4015 may determine the question of child custody (a family matter) by reference to the public law of a foreign state while simultaneously failing to give any weight to the reality of what is occurring in the private sphere of the relevant family (unless that is recognised by the applicable state law). ${ }^{44}$ While Tahiri does not provide a thorough

41 The serious harm that a woman may face in such circumstances and her need for protection by the international community has been recognised in Australia through acknowledgement that the Refugee Convention can apply to such situations. See, in particular, Minister for Immigration $v$ Khawar (2002) 210 CLR 1.

42 Catherine MacKinnon, 'Feminism, Marxism, Method, and the State: Toward Feminist Jurisprudence' (1983) 8 Signs: Journal of Women in Culture and Society 635.

43 Tahiri $v$ Minister for Immigration and Citizenship (2012) 293 ALR 526, 18.

44 There is a considerable body of feminist legal theory showing that the public/private distinction has been used in law to justify non-intervention by the state for the protection and advancement of women, while also creating gendered hierarchies within the private sphere: '[T] he crucial impact of feminist scholarship on family research has been to recast the family as a system of gender stratification. Because roles neglect the political underpinning of the family, feminists have directed attention outside the family "to the social structures that shape experience and meaning, that give people a location in the social world, and that define and allocate economic and social rewards".' Zinn quoting Hess and Marz Ferree in Maxine Baca, 'Family, Feminism and Race in America' in Nancy E Dowd and Michelle S Jacobs (eds), Feminist Legal Theory (New York University Press, 2003). 
examination of Afghan law, it presents a situation in which a woman may have sole custody/parental responsibility of her children within the private sphere of the family but no legal ability arising under an applicable system of law to determine where those children may live. ${ }^{45}$ This law subjugates the interests of a woman to her absent husband (and his family), and the logic of PIC 4015 is that using this law is an objective and rational manner of determining child custody because it is public law. ${ }^{46}$

The consequences arising from the application of PIC 4015 in such a situation can be further illustrated by considering the hypothetical scenario of the death of Mrs Tahiri's husband being established and her husband's family deciding to take the children to Australia without her. In such a situation, PIC 4015 would give effect to the custody rights of the husband's family while it may fail to recognise the need for Mrs Tahiri's consent because her custody rights/parental responsibilities do not arise under a system of public state law. Such an effect demonstrates how PIC 4015's focus upon custody rights as determined by public state law not only disempowers women based in the private sphere, but also operates without reference to them. ${ }^{47}$

Tahiri further illustrates how a law designed for the benefit of children does not include any consideration of the child's interests or perspectives. The terms of PIC 4015 are about matters affecting the child but not the child herself or himself. The law situates the

45 Javed Hussain Tahiri, 'Plaintiff's Submission', Submission in Tahiri $v$ Minister for Immigration and Citizenship, No M77/2012, 21 November 2012, 9. Having viewed the file, the plaintiff states that the decision-maker in Tahiri implicitly found that the mother was not a person who solely or jointly could lawfully determine where the children were to live. While the focus of the case was not on whether the mother had any such legal right (because it was clear she consented to the children's travel) the only legal ability to determine where the children could live identified in the case was that of the father and the father's family.

46 This reflects a notion, critiqued by feminists, of the public sphere as rational, in contrast to the private sphere as irrational and particular. See, for example, Margaret Thornton, 'The Cartography of Public and Private' in Margaret Thornton (ed.), Public and Private Feminist Legal Debates (Oxford University Press, 1994).

47 In such a scenario, PIC 4016 would then need to be considered. It requires consideration as to whether there is a compelling reason to believe that grant of a visa would not be in the best interests of a child. Mrs Tahiri's ability to travel with the children would be relevant to such a consideration. However, that is not a sufficient remedy for the shortcomings of PIC 4015 in failing to acknowledge and consider Mrs Tahiri's role and importance to the children, which in this hypothetical scenario creates a terrible situation of considering the best interests of children in escaping persecution as against their interests in being with their mother who has been their sole carer for many years. 
child only as subject to law and the will of others, not as a subject in her/his own right. Given this approach, it is unsurprising that it supports outcomes such as in Tahiri where children in an incredibly vulnerable situation were denied humanitarian visas without any consideration of their interests. The case of Tahiri is only one example of the operation of this law, which applies to skilled visa applicants, family visa applicants and business visa applicants. ${ }^{48}$

A re-evaluation of PIC 4015 is required by reference to the objectives sought to be achieved by the requirement.

\section{Reconsidering the objectives of PIC 4015}

The policy manual of DIBP discusses the purpose of PIC 4015 as being 'to assist Australia in meeting its obligations as a party to several international conventions relating to the protection of children under 18 years of age, such as the Hague Convention, ${ }^{49}$ the Convention on the Rights of the Child (CROC) and the Hague Convention on Protection and Cooperation in Respect of Intercountry Adoption'. The manual's discussion of the background to PIC 4015 further states that ' $[\mathrm{m}]$ igration law requires officers to consider the effect that granting a visa to a minor may have on the objectives of the Hague Convention', and identifies the convention's objectives incorporated into Australian domestic law as being to:

i. secure the prompt return of children wrongfully removed to, or retained in, any 'contracting state' (that is, any country that is a signatory to the Hague Convention), and

ii. ensure that the rights of 'custody' and 'access' under the law of the contracting state are effectively respected in other contracting states.

48 There are many interconnections between the interests of women and children. Given the situation raised in Tahiri, it is of interest to note an account by Graycar and Morgan of child custody law in Australia. They note a change from absolute custody rights being held by fathers to a situation in which custody was granted to mothers as occurring '[o]nce the equity courts were given power to consider applications for custody from mothers according to principles under which the welfare of the child came to be considered as paramount'. See Regina Graycar and Jenny Morgan, above fn 37, 258.

49 Convention on the Civil Aspects of International Child Abduction, 25 October 1980, Hague XXVIII (entered into force 1 December 1983). 
The Hague Convention addresses international child abduction by creating a framework for deciding the forum where child custody disputes will be decided. The general operating principle is that a child should be returned to their country of habitual residence for the resolution of a custody dispute. Consistent with this, PIC 4015 gives priority to the law of a person's home country, which was a focus for consideration in Tahiri. The problem is that, as the decision in Tahiri shows, PIC 4015 has a much broader application than the Hague Convention: it determines custody by reference to a child's home country regardless of whether there is a case of child abduction and regardless of whether the Hague Convention applies.

There was nothing to suggest a child custody dispute arose in the case of Tahiri - much to the contrary ${ }^{50}$ - yet PIC 4015 stopped Mrs Tahiri bringing her children to Australia. This law has been justified on the basis that it seeks to prevent child abduction yet it does not allow for consideration as to whether there is any prospect of child abduction occurring in cases to which it applies.

Furthermore, PIC 4015 operated to give effect to the law of Afghanistan, notwithstanding that Afghanistan is not a signatory to the Hague Convention. Thus no Hague Convention obligation arose for Australia in the circumstances of the case. Considering the discriminatory effect of PIC 4015, discussed above, and the justification of PIC 4015 as the means by which Australia upholds its Hague Convention obligations, it is of great concern that PIC 4015 prioritises the law of a foreign country regardless of whether that country even claims to adhere to the objectives of the Hague Convention. That convention only applies to children habitually resident in a signatory state. ${ }^{51}$ By failing to distinguish between signatory and non-signatory countries, this Australian law gives equal effect to the domestic law of countries

50 The facts accepted were that Mrs Tahiri was the only person to have any interest in the children - either in terms of asserting parental rights of custody or taking parental responsibility towards the children (as reflected in modern Australian family law norms concerned not to treat children as property).

51 Javed Hussain Taheri, 'Plaintiff's Submission', Submission in Tahiri $v$ Minister for Immigration and Citizenship, No M77/2012, 21 November 2012, 15, 16, referring to the Convention on the Civil Aspects of International Child Abduction, 25 October 1980, Hague XXVIII (entered into force 1 December 1983) art 4. 
that support the convention and countries that do not, including those countries opposed to the religious and gender neutrality of the convention..$^{52}$

Even where it does apply, the Hague Convention allows for more nuanced consideration of the circumstances of a case to advance its multiplicity of objectives. ${ }^{53}$ Balancing the general approach of the convention (that states should facilitate the prompt return of children to their country of habitual residence) are provisions that allow for consideration of exceptional circumstances. Article 13(a) states that there is no obligation to return a child where the petitioner was not caring for the child or exercising custody rights at the time of removal. Article 13(b) states that there is no obligation to return a child where there is a grave risk that the child would be exposed to 'physical or psychological harm' or placed in 'an intolerable situation'. Perhaps most relevantly to Tahiri, Article 20 provides that a country may refuse to return a child if return would conflict with the fundamental principles of the state relating to protection of human rights and fundamental freedoms. By contrast, PIC 4015 does not permit consideration of any of these significant matters, and in failing to do so has a practical operation that is contrary to the terms and spirit of the convention in some cases.

52 Sharma and Viswanathan state that most Islamic nations have not signed the Hague Convention because of differences such as wanting Sharia law to be a part of decision-making in relation to children. They also explain that for Muslim countries, such as Egypt, fathers are given custody of children after the age of dependence as a matter of law. Akanksha Sharma and Harini Viswanathan, above fn 39. Bowie identifies how Australian Courts have treated cases of child abduction differently, depending upon whether the child has been abducted from a country that is a signatory to the Hague Convention. The difference being that for non-signatory countries the welfare or best interests of the particular child is a paramount consideration, whereas for signatory countries this principle does not apply. She cites the High Court decisions of ZP $v$ PS (1994) 122 ALR 1 and De L $v$ Director General, NSW Department of Community Services (1996) 187 CLR 640: Krista Bowie, 'International Application and Interpretation of the Convention on the Civil Aspects of International Child Abduction' (March 2001).

53 Preamble, Convention on the Civil Aspects of International Child Abduction, 25 October 1980, Hague XXVIII (entered into force 1 December 1983). The convention's objectives are to confirm the paramount importance of the interests of children; protect children from wrongful removal or retention; establish procedures for children's prompt return to their state of habitual residence; and seek rights of access. 


\section{Conclusion}

The High Court's judgement in Tahiri focused attention upon the situation of a vulnerable woman and her children unlikely to otherwise come to public attention, while at the same time declaring that Australian law operated to exclude consideration of their personal circumstances from a determination critical to whether they would be permitted to resettle in Australia. Applying PIC 4015 limited consideration of child custody to the question of whether Mrs Tahiri's husband or his family had given consent to the children's travel. In its judgement, the High Court did not engage with the fact that the Afghan law is discriminatory, nor did it acknowledge the substantive responsibility that Mrs Tahiri had exercised as a sole parent in relation to her children. The constraints imposed by the limited nature of review available did not permit consideration of the welfare of the family or the best interests of the children.

It is important that Australia does not facilitate child abduction and seeks to specifically consider the welfare of vulnerable minors in making visa decisions. Achieving these aims in the context of a visa decision can be difficult, especially since it can require consideration of the interests of a party not involved in a visa application.

However, the potential difficulty of achieving such goals does not justify a law preventing consideration of circumstances relevant to a just outcome. The unintended consequences of the operation of PIC 4015 illustrated by Tahiri are the likely, perhaps inevitable, consequences of a law that seems to be crafted to minimise or eliminate evaluative and situational judgements in decision-making. The assessment required is about whether facts are in existence (such as whether the law of a home country allows a child to travel or whether parents have provided consent), not whether a child should, in the circumstances of a particular case, be refused a visa because that is likely to facilitate child abduction or be contrary to the interests of children and their parents/guardians. Justifying such an approach as superior because it is more objective denies the biases within the law. Limiting the matters decision-makers are permitted to consider also limits their capacity to make fair decisions. 
The unintended consequences of applying PIC 4015 highlighted by, but not limited to, the facts of Tahiri should motivate reconsideration of the terms of PIC 4015 to determine how its discriminatory impact upon women and adverse consequences for children may be reduced, and how policy objectives may be better achieved. This may well require acknowledgement of the importance of evaluative judgements and consideration of subjective circumstances, rather than a desire to exclude them from 'objective' decision-making.

\section{Bibliography}

\section{Articles, books, and reports}

Baca, Maxine, 'Family, Feminism and Race in America' in Nancy E Dowd and Michelle S Jacobs (eds), Feminist Legal Theory (New York University Press, 2003)

Graycar, Regina and Jenny Morgan, The Hidden Gender of Law (Federation Press, 2nd edition, 2002)

MacKinnon, Catherine, 'Feminism, Marxism, Method, and the State: Toward Feminist Jurisprudence' (1983) 8 Signs: Journal of Women in Culture and Society 635

Sharma, Akanksha and Harini Viswanathan, 'Extension of the Hague Convention to Non-Signatory Nations: A Possible Solution to Parental Child Abduction' (2011) 4 International Journal of Private Law 546

Thornton, Margaret, 'The Cartography of Public and Private' in Margaret Thornton (ed.), Public and Private Feminist Legal Debates (Oxford University Press, 1994)

UK Home Office, 'Pakistan Country of Origin Information (COI) Report' (9 August 2013) 


\section{Cases}

Axon v Axon (1937) 59 CLR 395

De L v Director General, NSW Department of Community Services (1996) 187 CLR 640

Minister for Immigration \& Multicultural \& Indigenous Affairs v VSAF of 2003 [2005] FCAFC 73 (10 May 2005)

Minister for Immigration v Khawar (2002) 210 CLR 1 Tahiri, Javed Hussain, 'Plaintiff's Submission', Submission in Tahiri v Minister for Immigration and Citizenship, No M77/2012, 21 November 2012

Tahiri v Minister for Immigration and Citizenship (2012) 293 ALR 526

Tahiri v Minister for Immigration and Citizenship [2012] HCATrans 336 (7 December 2012)

ZP v PS (1994) 122 ALR 1

\section{Legislation}

Family Law Act 1975 (Cth)

Migration Act 1958 (Cth)

Migration Amendment Regulations 2000 (No. 2) (Cth)

Migration Regulations 1994 (Cth)

\section{Treaties}

Convention on the Civil Aspects of International Child Abduction, 25 October 1980, Hague XXVIII (entered into force 1 December 1983)

\section{Other}

Australian Human Rights Commission, The Convention on the Elimination of All Forms of Discrimination against Women (CEDAW): Sex Discrimination - International Activities. Available at: www.humanrights.gov.au/convention-elimination-all-formsdiscrimination-against-women-cedaw-sex-discriminationinternational 
Bowie, Krista M, 'International Application and Interpretation of the Convention on the Civil Aspects of International Child Abduction' (March 2001). Available at: www.familycourt.gov.au/wps/ wcm/connect/872fc343-d6e8-4ab3-84ba-b3f58662ec4e/bowie. pdf?MOD $=$ AJPERES \&CONVERT_TO $=$ url $\&$ CACHEID $=872 \mathrm{fc} 343-$ d6e8-4ab3-84ba-b3f58662ec4e

Tahiri v Minister for Immigration and Citizenship Case No. M77/2012. Available at: www.hcourt.gov.au/cases/cases_m77-2012 
This text is taken from Unintended Consequences: The impact of migration law and policy, edited by Marianne Dickie, Dorota Gozdecka and Sudrishti Reich, published 2016 by ANU Press, The Australian National University, Canberra, Australia.

The papers published in this book arose from an inaugural conference on migration law and policy at ANU College of Law, held in October 2013. They are reprinted here with minor amendments. 